\title{
The Students' Reception of @Lambe_Turah's Gossip Account Posts in Public Relation Students at Mercu Buana University
}

\author{
Nadira Sekar Lintang ${ }^{1}$, Achmad Jamil ${ }^{2}$ \\ \{nadirasekar2@gmail.com ${ }^{1}$, achmad_jamil@mercubuana.ac.id²\} \\ Universitas Mercu Buana, Jakarta, Indonesia ${ }^{12}$
}

\begin{abstract}
The presence of @Lambe_Turah gossip account that shares information about the life of celebrities in Indonesia, made Instagram users get the latest information about Indonesian celebrities, or other general information quickly, especially for students from Lambe Turah. This research used qualitative research as the method with a reception analysis approach. The objective of this research is to find out the student receptions, especially in Public Relations students 2016 at Mercu Buana University Jakarta regarding the posting of @Lambe Turah's Instagram account. This research showed that data obtained through in-depth interviews with ten respondents. The result of the data described through three positions, they are the dominant hegemony of four people, the negotiation position of six people, and no one is in the position of opposition. The result of this research showed that the majority of respondents stayed in a negotiated position.
\end{abstract}

Keywords: Students’ Receptions, Gossip, Instagram Posts, @Lambe_Turah account, social media

\section{Introduction}

(a) Lambe Turah is one of the gossip Instagram accounts that contains news about celebrities and public figures in Indonesia. Unfortunately, not all of the posts that @Lambe_Turah shared about the celebrities are useful. @Lambe_Turah often had problems with some Indonesian artists because their posts were considered controversial, offending, and disturbing the personal lives of celebrities, such as Luna Maya, Nikita Mirzani, Syahrini, and Ariel Noah. Besides the infotainment, @Lambe Turah also often shares information about popular issues that exist in society, such as natural disasters and other hot news. Based on the research about Lambe Turah by Kurnia, Lambe Turah does not only share information about celebrities, but also artists, political figures, or other things that have a unique, funny, or even embarrassing side [1].

The four phenomenologists in the research describe from the epoch stage to the synthesis of meaning and essence, it can be concluded that Lambe Turah is a gossip account whose truth value cannot be held responsible because it does not display the source, but only in the form of photos or videos, where the owner and the image taker are not. known identity. Other than that, @Lambe_Turah's posts are frequently has been published on online news websites in Indonesia. Instagram is one of the popular social media in modern society today. Almost all people have an Instagram account. In the past, the Instagram user was only used 
as a personal account, which was used to share daily photos with captions. However, in this digital era, Instagram has a new role in fulfilling people's needs for news and getting various information. Unfortunately, according to the results of a poll that uploaded by @wartabromo on their Instagram story [2] that the researcher accessed on February 19th 2020 at 08:40am WIB, there are 192 netizens that 89 of them, or $48 \%$ of voters claimed that they could not distinguish between a hoax and true information. Meanwhile, 52\% of voters or 103 of them admitted that they were able to distinguish between hoax or true information.

According to Irawan \& Fridha on their journal, @Lambe_Turah account utilizes the opportunity in sharing information freedom and the owner of this account's legitimation is initiated on neoliberalism ideology [3]. This statement fits the pattern of today's netizens who are unable to distinguish between fact and fiction. It means that Lambe Turah's account owners' orientation is the market. The freedom of information is indicated by people that give the information sources without verification of the information to the sources. In other words, one of the important aspects that beat up information validation is the speed of information spreads.

In communicating, people do not always use words to express something or information. They can also use symbols to communicate with others. For example, when we are pointing our thumb at someone, it means that the person who is talking with us is doing something good. So, to tell something or information, a communicator does not have to use words with the communicant. In accordance with Schwartz, he said that communication is using meaningful symbols on the process of delivering information's, ideas, or emotions between people and systems [4]. Thus, communication is a way to express something to other people.

It is about sixty years; the 'media' word is the plural form of the 'medium' word which has been used as a collective singular term, becoming 'media'. s. Lister, et al. stated that New Media is a new medium of intermediation, in which all forms of New Nedia as information and communication technology products now and in the future along with digital computers play an important role in it [5]. The appearance of New Media does not erase the existence of old media that already existed in people's lives, because it is the result of the development of old media such as newspapers, television, and radio which are still around today. New Media is starting to replace the human needs to access technology that there is no interaction in it in the past. With new media like the internet, humans can access it without being limited to distance, space, and time. Moreover, in the era of new media that called as 'citizen journalism', where there is a change from "audience" to "user", and from "consumer" to "producer".

Social media is a website which is based feature that can form networks and allow people to interact in a community. According to Albarran, social media are applications that people usually use in expanding and depending their social networking sites, including the locationbased service, gaming, the information multimedia posts and other aspects [6][7]. Puntoadi added that the benefits of social media are determining the desired personal branding, finding the right environment, learning how to communicate, for consistency, and as a mix of the media [8]. The fantastic marketing results through Social media is "people don't watch TV anymore; they watch their mobile phones". Hence, social media is a technology to expanding the networking sites.

Information integration theory focuses on the way communicators to collect and organize information about other people, objects, other people and ideas to form attitudes. Attitude is a predisposition to act in a positive or negative way toward some object. The approach that the information integration theory proposed is one of the most popular approaches that explain how the formation and change of attitudes can occur. This theory said that cognition 
is a process of knowing, understanding, and learning something that is a system of interactions in which information has the potential to influence individual trust or attitude. McQuail expressed that attitude is a collection of information about an object, person, situation, or experience [9]. Attitude changes because new information adds to the attitude or the information is able to change the assessment of the weight or direction of other information. Each information usually will not influence attitudes directly because attitudes consist of a number of trusts that can reject new information.

Informal communication (the grapevine) is usually spread through rumors or word of mouth from one person to another in an organization where the truth cannot be guaranteed because it sometimes contradicts with the company. In order to make informal communication can be useful, a leader must be able to use this route to ease formal company communications. This informal communication should not appear the rumors that unsettling the employees. Rayadu (1998) in Deepa claimed that grapevine communication comes spontaneously and is one of the effective ways of giving information fastly [10]. So, grapevine is an informal communication that is faster, and more effective in transmitting the information. Instagram is a mobile application based on iOS, Android, and Windows Phone where users can take a video or video, edit with some filters, and post them. In accordance with Winarso on daily social [11], Instagram was originally developed by a startup called Burbn, Inc, which was held by Kevin Systrom and Mike Krieger. They succeeded in bringing Facebook to buy Instagram for $\$ 1$ billion. In 2012, Instagram eventually acquired by Facebook.

The birth of 'Reception Research' in mass communication research goes back to Stuart Hall's [12] Encoding and Decoding in television discourse. Pertti uttered that reception research in media studies is related to cultural studies, and the Birmingham Center suggests that reception theory has other roots [10]. Stuart Hall explained that the audience decodes the media message through three possible positions, are: 1. Dominant Hegemony Position, which is a situation where the audience receives messages conveyed by the media. 2 . Negotiation position where is the public generally accepts the dominant ideology but rejects its application. 3. Opposition Position, which is the audience rejects the meaning of the message. Hence, in reception, there are encoding and decoding. It also has three positions; they are dominant hegemony negotiation and opposition position.

\section{Research Method}

This research was qualitative research that used the reception analysis as a method. In general, people usually mention the reception theory as audience reception in the communications analysis models. Reception theory is a reader response literary theory version that asserts the reader's reception in creating or understanding the meaning from a literary text. Ratna said that the aim of reception analysis is to analyze various problems of the social sciences and humanities, such as: democracy, race, gender, class, nation-state, globalization, freedom, and societal problems in general [10].

Reception analysis is a specific part of audience studies that try to examine the actual process deeply, in which media discourse is assimilated through the practice of discourse and its audience culture. The paradigm that the researcher used in this research is the constructivist paradigm. Honebein (1996) in Adom et al. described that constructivist philosophical paradigm is an approach that declares that people build their comprehension 
and their knowledge by experiencing things and reflecting them on their impressions [10]. The researcher did the interview with Public Relations students 2016, Mercu Buana University, Jakarta, who followed the Instagram gossip account @Lambe_Turah as the object of research. The researcher took 10 representatives of male students and female students of Public Relations 2016 at Mercu Buana University in Jakarta as the primary data. For the secondary data, the researcher took several books, articles, journals, websites, and other sources related to research on social media.

In this research, researcher used data collection methods with a mixture of various data sources and various methods. The data analysis technique in this research is examined data that has been obtained from interview data, documentation, and other data sources. Then, the researcher categorized the data to make it more structured and clearer. After that, the researcher provided a clear and reasonable explanation about the data that has been obtained and made it become a clear report. The validity technique of the data in this research are: 1 . Performed a member check to find out how far the data obtained was corresponding with what was provided by the data provider. 2. Confirmability that is the objectivity of qualitative testing is also called as the confirmability test. The research can be said to be objective if the results of the research have been agreed upon by more people.

\section{Results and Discussion}

@ Lambe_Turah is a place for netizens to looking for the latest news or information which is related to the entertainment, or about the general viral issues in society. @Lambe_Turah always provides the latest information every day, and the account can even upload more than ten posts in a day. However, it is not uncommon for posts from this account to be deemed to be able to damage the image and reputation of the celebrities that being reported, because the news conveyed by this account is news or information that cannot be confirmed yet, because the information that shared by this account cannot be clearly identified.

Based on the research by Juditha, Lambe turah has its own influence and power in forming the public opinion [13]. Moreover, it is added with followers' comments which tend to further strengthen the formed public opinion. The power of the followers on the @lambe turah account can be seen from their hateful comments towards an artist, but some of them are neutral and constructive. @Lambe turah account is able to have the power to influence netizens by creating a certain dominant way of thinking or discourse, which is considered true so that people believe the discourse is true.

In analyzing the results of the interview from the results of the result data, the researcher divided it into several questions, they are:

a. Do you think the information provided by the account is true?

b. Does the information submitted by the account change your view of this?

c. Does the account share complete information?

d. Do you get the latest information from the account?

e. When you got the information, did you keep it to yourself or did you share it with other friends?

f. Do you feel that the information provided by the account is sufficient for the information you need? 
g. Are you influenced by other people or really want your own when you follow the account?

h. What is your view of the presence of the @Lambe_Turah gossip account along with the information shared by that account?

In this research, the researcher also described the opinion of the informants regarding the reception of the informants regarding the presence of the @Lambe_Turah account along with the information they convey. From the results of the interview, the researcher categorized the informants based on the food they produced, including the dominant hegemonic meaning, negotiation and opposition based on what Hall stated in Zaid [13]:

a. Dominant hegemonic reading is that the reader that in line with program codes (which contain about values, attitudes, beliefs and assumptions) and fully accepted the meanings that put forward and desired by the program maker.

b. Negotiated reading is the reader to a certain extent in line with program codes and essentially accepts the meaning offered by the programmer but modifies it in such a way as to reflect his personal position and interests.

c. Oppositional 'counter' hegemonic reading is that the reader that does not line up with program codes and rejects the meaning or reading offered and then determines his own alternative frame in interpreting the message or program.

From eight respondent that submitted to ten respondents or informants, there is the following results were obtained:

\begin{tabular}{llll}
\hline Informant's name & Dominant & Negotiation & Opposition \\
\hline Informant 1 & 6 & 2 & - \\
Informant 2 & 2 & 6 & - \\
Informant 3 & 3 & 4 & - \\
Informant 4 & 6 & 2 & - \\
Informant 5 & 2 & 5 & 1 \\
Informant 6 & 5 & 3 & - \\
Informant 7 & 3 & 6 & - \\
Informant 8 & 2 & 5 & - \\
Informant 9 & 5 & 3 & - \\
Informant 10 & 2 & 5 & - \\
\hline
\end{tabular}

The researcher also examined how the reception of the informants regarding the presence of the@Lambe_Turah Instagram account. Is the presence of the @Lambe_Turah and the information it shares can increase knowledge of the latest information and are there any benefits generated by this account? Based on interviews and analysis results, there are the result of this research:

a. There are ten informants who form different interpretations of the presence of the @Lambe_Turah gossip account. The informants still doubt the truth of the information shared by the@Lambe_Turah Instagram account.

b. 2.Informants expressed their opinion about whether the information conveyed by the @Lambe_Turah Instagram account changed their view of something and the five informants felt they did not always fall for the information shared by the @Lambe_Turah Instagram account.

c. Several informants also predominantly said that the information shared by the @Lambe_Turah sudqah Instagram account was quite complete. 
d. Most of the informants still felt that they had not received the latest information. These informants feel that they only get the latest information from the@Lambe_Turah Instagram account.

e. Most of the informants in this study predominantly tell their other friends when they get the latest information or news from the @ $a$ Lambe_Turah Instagram account.

f. Informants are in a different position when it comes to whether they have sufficient information to suit their needs. Two out of five informants stated that they had not received sufficient information, the other two informants felt that they had received sufficient information according to what they needed.

g. The informants in this study have full awareness when following or following the @Lambe Turah Instagram account without being influenced by anything.

h. The views of the five informants regarding the presence of the @Lambe_Turah Instagram account were different, the informants had their own views on this. Most of the informants predominantly said that the presence of the @ Lambe Turah Instagram account helped them to get the latest information that was hotly discussed.

\section{Conclusion}

The conclusions of this research are from ten informants, still doubted the truth of the information from@Lambe Turah. They thought that they did not always fall for the information shared by the @Lambe_Turah, and it could not change their views of something. Several informants said predominantly that the information from @ Lambe Turah was quite complete. But, most of the informants still felt that they did not get a lot of the latest information from@Lambe_Turah, and they would retell the information that they got from that account to other friends. The informants had different positions when it comes to whether they had sufficient information to suit their needs from@Lambe Turah. Half of the informants stated that they had not received sufficient information; the other informants felt that they had received sufficient information that suitable for their needs. The informants in this research had full awareness when they followed@Lambe_Turah without being influenced by anything. Most of them said that @Lambe_Turah helped them to get the latest information that was hotly discussed.

After conducting the research and seeing the results obtained, there are suggestions that the researcher provide. In academic suggestion, for future researchers who will carry out similar research are expected to be able to seek information from trusted media and the clarity of the source can be justified. The further searchers can find as many references as possible for the theory concerned that will be used in their research. In practical suggestions, researcher felt that there are several things that can be applied in practical life related to this research. For readers, especially social media users to do not spreading things that they should not spread. Other than that, netizen who are the recipients of information should double check the information on other reliable sources.

\section{References}

[1] Kurnia, "Sebagai Media," vol. 7, no. 2, pp. 180-189, 2018.

[2] " $47 \%$ Netizen Instagram Sulit Identifikasi Berita Hoax - kumparan.”.

[3] R. E. Irawan and M. Fridha, "Critical Discourse Analysis of Lambe Turah Instagram Account as Post Truth Era Inauguration: A Critical Discourse Analysis of Lambe Turah Instagram 
Account on Second Nyonyah Edition,” Int. Conf. Media Commun. Stud., vol. 260, no. January 2018, pp. 185-188, 2018.

[4] S. H. Schwartz, "An Overview of the Schwartz Theory of Basic Values," Online Readings Psychol. Cult., 2012.

[5] M. Lister, J. Dovey, S. Giddings, K. Kelly, and I. Grant, New Media: A Critical Introduction, vol. 44 , no. 04. 2006

[6] A. B. Albarran, Introduction. 2013.

[7] K. Saddhono, A. Hasibuan, and M. I. Bakhtiar, "Facebook as A Learning Media in TISOL (Teaching Indonesian to Speakers of Other Languages) Learning to Support the Independency of Foreign Students in Indonesia," J. Phys. Conf. Ser., vol. 1, 2019.

[8] D. Puntoadi, "Menciptakan Penjualan via Social Media," Jakarta: PT Gramedia, 2011.

[9] D. McQuail and A. Dharma, AgusRam, Teori Komunikasi Massa, 2nd ed. Jakarta: Erlangga, 1987.

[10] S. Deepa, "an Exploratory Study in Indian Context," no. 49, 2016.

[11] dailysocial.id, "Apa Itu Instagram, Fitur dan Cara Menggunakannya? Dailysocial," Dailysocial.Id. 2020.

[12] S. Hall, "Deviance, politics, and the media," in Deviance and Social Control, 2018

[13] C. Juditha, "HEGEMONI MEDIA SOSIAL: AKUN GOSIP INSTAGRAM @ LAMBE TURAH SOCIAL MEDIA HEGEMONY : GOSIP INSTAGRAM ACCOUNT @ LAMBE TURAH PENDAHULUAN Saat ini berita terbaru tentang para selebritis tidak hanya diperoleh dari tayangan infotainment di televisi saja , ta," pp. 16-30, 2018. 